\title{
USER ADOPTION OF MANDATORY E-GOVERNMENT SYSTEMS: NOTARIAL SYSTEM IN ALBANIA, AN EMPIRICAL ANALYSE
}

\author{
Agim Kasaj $^{1}$
}

\begin{abstract}
E-Government has high priority for governments worldwide, with much effort and money being invested into government digital initiatives. For such efforts to be worthy, a high rate of adoption of egovernment is needed. Technology adoption is one of the most mature areas in information technology (IT) research and many adoption models have been developed for this purpose. Most studies in this field have been focused on voluntary use of systems and mainly from a business context, with minor emphasize on an egovernment. A major distinction between technologies of e-government and other online technologies, is that the use of certain e-government technologies is mandatory, rather than voluntary. This paper provides a short introduction of e-government, followed by a review of the most well-known information technology (IT) adoption models at the individual level. Using previous research results, the study will identify the determinant constructs and their relationship for adoption of the digital notarial system of Albania. Finally, the paper proposes a theoretical framework for private professional adoption of mandatory e-government information systems.
\end{abstract}

UDC Classification: 658.3, DOI: http://dx.doi.org/10.12955/cbup.v4.810

Keywords: e-government, technology adoption, notarial system, Albania, mandatory use.

\section{Introduction}

Notarial services play a crucial role in the well-functioning of modern countries. In direct and indirect ways, it serves to ameliorate and respond to governments, businesses, and citizen's demands. Considering life dynamics, possibly everyone at some stage will need to obtain notarial services, such as, business contracts, power of attorney, real estate purchase, attestations, credit loans, written declarations, company statutes, and testaments, especially in countries that operate under civil law. The range of notarial services is expanding, as legislation of countries becomes more complex and the free movement of people, services, and goods are promoted between countries and regions throughout the world.

There are two main types of notaries in the world: 1) common-law notaries (i.e., public notaries), found in United States of America, Canada, United Kingdom, and Australia and 2) civil-law notaries, found in most European countries and Latin America. The notaries in civil law are well trained, government-licensed private professionals (Malavet, 1995). In comparison to common-law notaries, civil-law notaries have greater legal power. The Albanian notarial service is a civil-law type. This means that notaries in Albania have strong legal power (similar to judge decisions) and can affect many aspects of business and individuals' lives. Many legal services have a monopoly on the notaries.

As in all other service businesses, the notarial service needs to adapt to the digital era and embrace its challenges. In Albania, the notarial service has been part of the national strategies and objectives for the digitalization of services offered to citizens, businesses, governmental institutions, and third parties.

In view of Albania's European integration agenda, great emphasis has been placed on automation and information and communication technology (ICT) to provide more effective services for the population as well as prevent corruption. Nevertheless, the adoptions, effectiveness, and efficiency of e-government services in Albania remain a critical issue, upon which neither the government nor the private players have devoted sufficient time nor effort in monitoring and measuring such. Thus, it is necessary for all e-government services to be critically discussed, systematically measured, and monitored with unbiased methodology. As a response, this study aims to identify the determinants in adopting use of the digital notarial service of Albania and proposes an adapted theoretical framework for private professional adoption of mandatory e-government information systems.

\footnotetext{
${ }^{1}$ Agim Kasaj, Faculty of Economics and Information Technology, European University of Tirana, Albania, akasaj@gmail.com
} 
A major distinction between e-government systems and other online technologies, such as, ecommerce, is that the use of certain e-government technologies is mandatory, rather than voluntary (Warkentin, Gefen, Pavlou, \& Rose, 2002). Digital notarial is a notable example of a mandatory egovernment technology in which the notaries are required by law to use the system and digitally archive the legal documents they produce, as well as their transactions. While prior research has been focused primarily on voluntary technology from the consumer context, this work focuses especially on mandatory e-government services.

This paper provides a short introduction of e-government, followed by a review of the most wellknown information technology (IT) adoption models, and based on previous research results, identifies the determinant constructs and their involvement in adopting a digital notarial system. The study focuses on the perspective of e-government by studying the factors that explain the system adoption of digital notarial system by end users. The end users of this system are notaries, trained private professionals who are licensed by the government.

\section{E-Government and Digital Notarial}

The digital notarial system is a governmental service, despite being offered by private professionals. E-Government involves the use of ICT by the government for providing information and public services to the people (United Nations Department of Economic and Social Affair, 2014). EGovernment is described as "the use of technology to enhance access to, and delivery of, government services to benefit citizens, business partners, and employees at local, municipal, state and national levels" (Deloitte Research, Deloitte \& Touche, \& Deloitte Consulting, 2000). E-Government includes electronic interactions of three types, i.e., government-to-government $(\mathrm{G} 2 \mathrm{G})$; government-to-business (G2B); and government-to-consumer (G2C).

E-Government implementation can significantly increase benefits, such as, improved efficiencies; greater access to services; greater accountability, transparency, and citizen empowerment; lowered costs; time for services; improved interactions with citizens, other government organizations, businesses, and industry; and better relationships between government and the private sector (Gupta, Dasgupta, \& Gupta, 2008). Increased use of e-government by citizens also leads to increased trust in local governments and to positive attitudes towards e-government processes. In contrast to traditional government processes, "e-government is notably characterized by (a) the extensive use of communication technology, (b) the impersonal nature of the online environment, (c) the ease by which information can be collected, processed (data-mined), and used by multiple parties, and (d) the newness of the communication medium" (Warkentin et al., 2002, p. 2).

The government of Albania implemented a digital notarial system for the first time in 2012, as part of the Digital Albania Initiative. This system was disruptive to the way the notaries previously worked to comply with legal requirements. The notaries had to switch from $100 \%$ manual work to a digital system where use was mandatory. Every notary was given access to the digital notary system where they had to register all their daily transactions and archive all legal documents they produced. By using this system, they had to communicate with other governmental institutions to obtain documents for specific services to the citizens.

\section{Existing Models of Technology adoption}

Technology adoption is one of the most mature areas in information technology (IT) research and numerous models have been developed for this purpose. These models are grouped into two types: 1) technology adoption models at the firm level such as digital object identifier (DOI; Rogers, 1995) and the technology organization environment (TOE) framework (Tornatzky \& Fleischer, 1990) and 2) technology adoption models at the individual level, such as, theory of reasoned action (TRA; Ajzen \& Fishbein, 1977; Fishbein \& Ajzen, 1975); motivational model (MM; F. D. Davis, Bagozzi, \& Warshaw, 1992); technology acceptance model (TAM; F. D. Davis, Bagozzi, \& Warshaw, 1989; F. Davis, 1989); technology acceptance model 2 (TAM 2; Venkatesh \& Davis, 2000); technology acceptance model 3 (TAM3; Venkatesh \& Bala, 2008); theory of planned behavior (TPB; Ajzen, 1985, 1991), unified theory of acceptance and use of technology (UTAUT; Venkatesh et al., 2003); and unified theory of acceptance and use of technology II (UTAUT2; Venkatesh, Thong, \& Xu, 2012). Because end users of digital notarial are individuals (notaries), this study examined the 
adoption at the individual level. There are many models developed to explain the individual adoption of IT. This study only focused on theories regarding technology adoption, with special focus on those adapted for workplace environments. The most used theories of technology acceptance at the individual level are the TRA (Ajzen \& Fishbein, 1977; Fishbein \& Ajzen, 1975), MM (F. D. Davis, Bagozzi, \& Warshaw, 1992), TPB (Ajzen, 1985, 1991), decomposed theory of planned behavior (Taylor \& Todd, 1995), TAM (F. Davis, Bagozzi, \& Warshaw, 1989; F. D. Davis, 1989), task technology fit (TTF; Goodhue \& Thompson, 1995), TAM2 (Venkatesh \& Davis, 2000), UTAUT (Venkatesh et al., 2003), TAM3 (Venkatesh \& Bala, 2008), and UTAUT2 (Venkatesh, Thong, \& Xu, 2012).

\section{Theory of Reasoned Action (TRA)}

The theory of reasoned action (Figure 1) is one of the most fundamental and influential theories of human behavior. It has been used to predict a wide range of behaviors. It is one of the first models to be used in the context of technology acceptance research. This theory is based in the field of social psychology and is comprised of the predictive factors 'subjective norm' and 'attitude toward behavior'. In this context, social norms describe "the person's perception that most people who are important to him think he should or should not perform the behavior in question" (Fishbein \& Ajzen, 1975 , p. 302). This is the perceived as approval or disapproval of the person's actions by a group (e.g., co-workers or friends) or a person (e.g., chief, supervisor or friend) who the person normally views as important.

Figure 1: Theory of reasoned action (TRA)

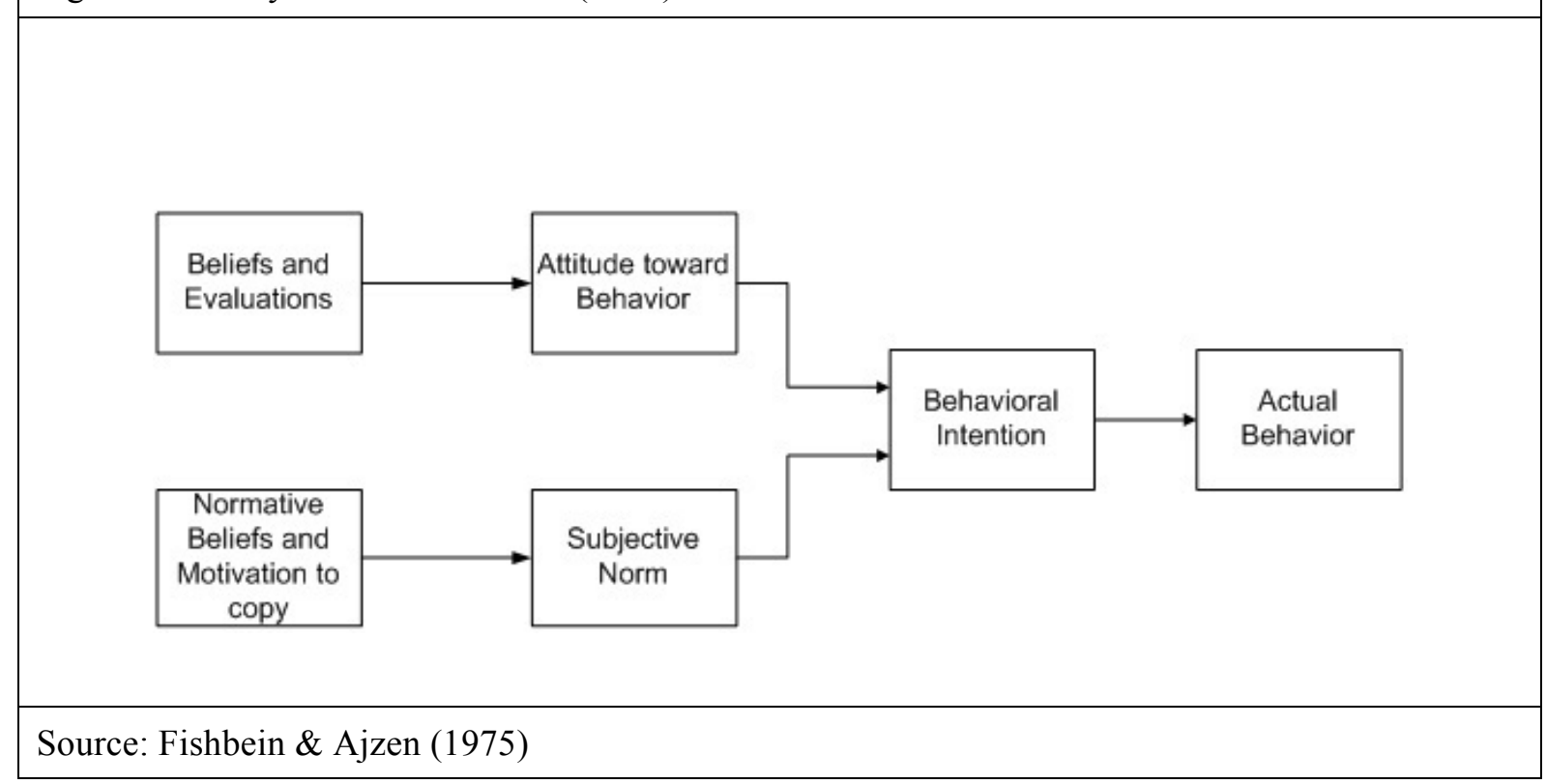

The 'attitude toward behavior' is "an individual's positive or negative feelings (evaluative affect) about performing the target behavior" (Fishbein \& Ajzen, 1975, p. 216).

The behavior of an individual is regarded as being predictable, based on the rules that have been set by the surrounding society, and the approval anticipated by the individual that results from an action observable by the society. This means such a model has certain limitations when used in the context of technology acceptance and prediction for future use of technology.

The key limitations of the TRA, in terms of applicability to different situations, are the conscious control of the behavior by the person, an informed choice made possible by fully availability of information to the person, and, finally, the role of choice in a given situation (Sheppard, Hartwick, \& Warshaw, 1988).

The TRA has been successfully used in many studies to predict people's behavior with regard to definite behavioral goals. 


\section{Motivational Model (MM)}

The MM (Figure 2) was built based on the TRA, and confirmed the valuable predictive power of the approach. The MM is based on psychological research into different factors affecting actions to predict the interaction with and acceptance of systems. A distinction between 'extrinsic' and 'intrinsic' motivation differentiates between a perceived external usefulness and reinforcement of the performed behavior, and an inner urge to perform a certain action without any external feedback as a motivational trigger.

Figure 2: Motivational model (MM)

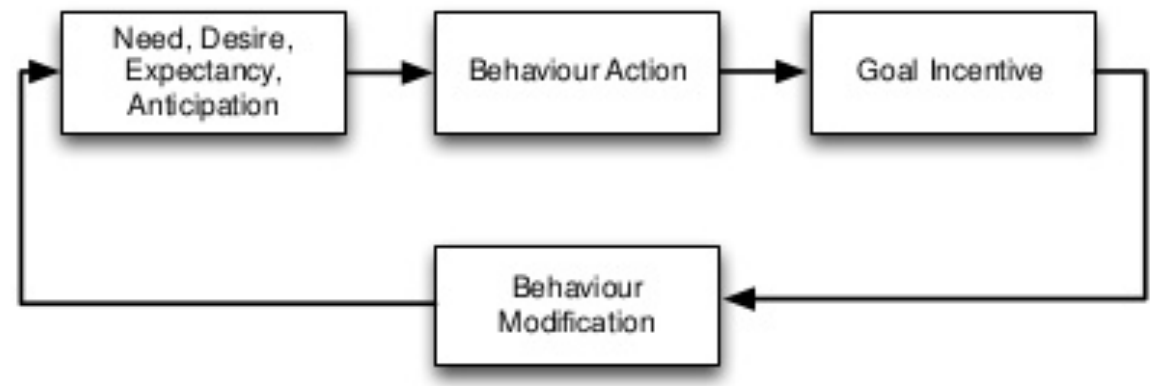

Source: F. D. Davis, Bagozzi, \& Warshaw (1992)

These external reinforcements are more likely to be found in an organizational context than in a private setting. In organizational settings, social pressure is likely to be more consistent than private ones. However, internal and external motivations can take different forms depending on the underlying motivational structure of a person.

\section{Technology Acceptance Model (TAM)}

The TAM (Figure 3), introduced by F. D. Davis in 1989, was adapted from TRA. The TAM was designed to predict information technology acceptance and usage, mainly in the workplace environments. Even though it is a parsimonious model, it can explain user behavior in a broad range of technologies and contexts. According to TAM, there are two particular beliefs 'perceived usefulness' and 'perceived ease of use' that are primary relevant for computer acceptance behavior. Perceived ease of use is "the degree to which a person believes that using a particular system would be free of effort" (F. D. Davis, 1989, p. 320). Perceived usefulness is defined here as "the degree to which a person believes that using a particular system would enhance his or her job performance" (F. D. Davis, 1989, p. 320).

Figure 3: Technology Acceptance Model (TAM)

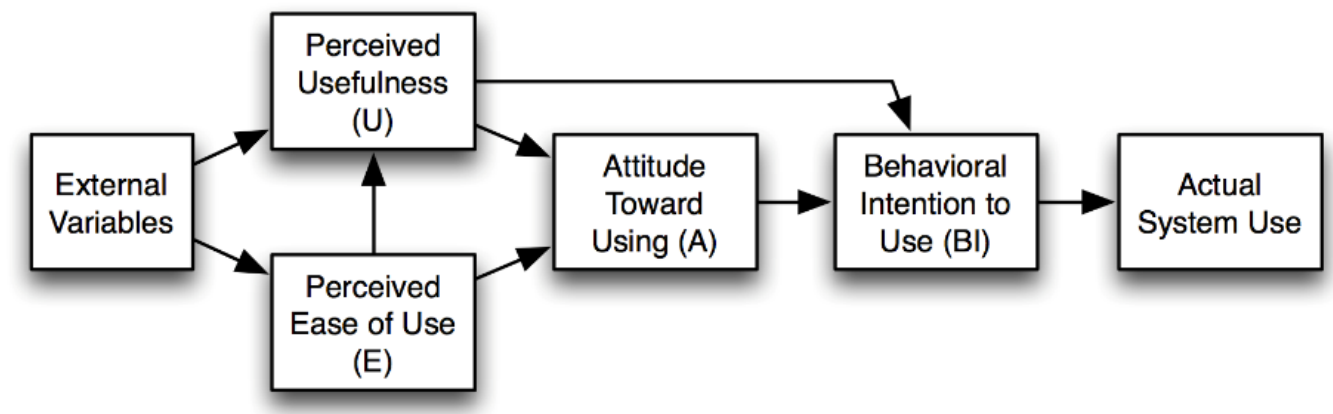

Source: F. Davis, Bagozzi, and Warshaw (1989), F. D. Davis (1989)

The individual's decision to make use of information technology is based on different factors that are related to inner-psychic processes, pressures of the (social) environment, or affordances and implications of the technology itself. The importance of understanding technology adoption decisions 
can give organizations a competitive advantage. The TAM has been one of the most used models in many studies that has been validated (Brown, Venkatesh, \& Goyal, 2012; Min \& Park, 2008).

\section{Theory of Planned Behavior (TPB)}

Ajzen $(1985,1991)$ reviewed and extended the original TRA model, after several limitations and difficulties in predicting behavior, especially when behavior was not completely voluntary, as identified by IT research, based on TRA. Like the TRA, the TPB (Figure 4) assumes that an individual's intention to perform a certain behavior is a sound indicator of actual behavior (Ajzen, 1991). The initial TPB, formulated by (Ajzen, 1985), did not evaluate the actual performance of behavior, but rather the attempt to perform certain behavior. Ajzen (1991) presented a review of several studies that successfully used TPB to predict intention and behavior in a wide variety of settings. The TPB extended TRA by adding the construct of perceived behavioral control. In TPB, perceived behavioral control is theorized to be an additional determinant of intention and behavior. This new core construct describes the "perceived ease or difficulty of performing the behavior" (Ajzen, 1991, p. 188). The TPB has been successfully applied to the understanding of individual acceptance and usage of many different technologies.

Figure 4: Theory of planned behavior (TPB)

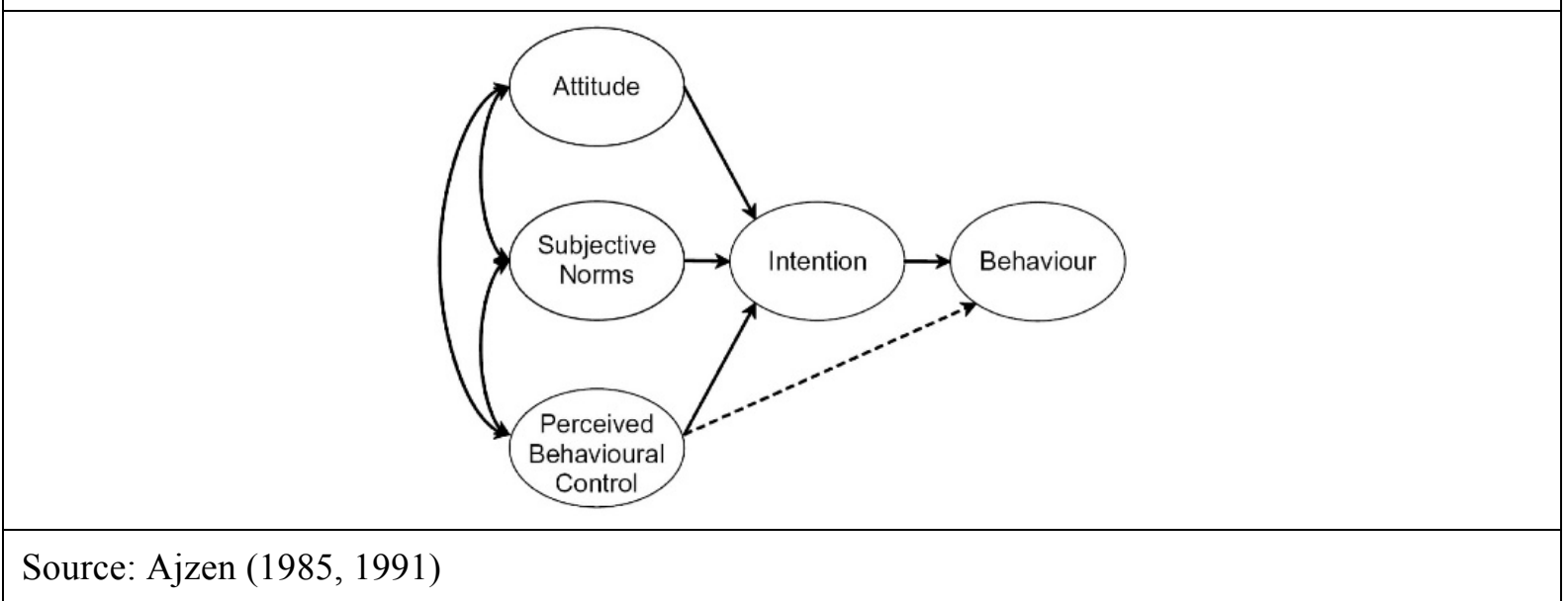

The TPB is the model resulting from three factors (Figure 4). Perceived behavioral control is one of the factors that, at a later stage of the development of technology acceptance models, would differentiate the more specific models from those with more general applicability. Meta-studies of the TPB showed that large variance remains unaccounted for with both 'intention to use' and 'actual behavior'. In general, approximately $39 \%$ of the variance in 'behavioral intention' and around $27 \%$ of variance in 'actual behavior' are explained when using the TPB (O'Connor \& Armitage, 2003).

From a research perspective, it is reasonable to consider the introduction of a variable to capture the variance introduced into the model by non-volitional conditions of the users. For instance, studies of workplace related technology, such as new developments in information technology, are unlikely to be a fully optional interaction in most circumstances.

\section{Technology Acceptance Model 2 (TAM 2)}

The original TAM was extended based on previous research and four longitudinal studies (Venkatesh $\&$ Davis, 2000). The longitudinal studies addressed the combination of voluntary and mandatory use, thereby tackling the potential issues that the TPB had raised with the inclusion of PBC. While this aspect of choice or behavioral control was not included in the original TAM (F. D. Davis, 1989), it exceeded the amount of variance explained by the TPB (Venkatesh \& Davis, 2000).

The step from the TAM to the TAM2 (Figure 5) added more complexity to the original model, while bringing it closer to other existing models, such as the TPB or the TRA. Additions made to the original TAM can be separated into two distinct groups: social influence processes based on social interactions and group behavior, and cognitive instrumental processes related to the performance of the technology and its impact on work. 
Within the context of social interactions, the construct 'voluntariness' was added to the TAM to support the PBC. This construct was set up as a moderating factor in the new model between subjective norms and the behavioral intention to use a technology. Subjective norms, which originated from the TRA and was included in the TPB, was a new addition to the model. This factor was placed in close relation to an image, which was another factor aimed at social interaction, identity, and group norming. Both factors were set up in the new model for 'perceived usefulness', while 'subjective norm' was also hypothesized to impact on behavioral intention. This impact was evident in the comparison of the four longitudinal studies. Finally, the construct 'experience' was placed as a moderating factor between subjective norm and both, 'perceived usefulness' and 'intention to use'.

With regard to the cognitive instrumental processes, three constructs were added to the original TAM model. All three new constructs in this group were hypothesized to impact on the TAM core construct 'perceived usefulness'. The construct 'job relevance' was included in the model to gather information with regard to the matching between the technology and requirements of the tasks to be performed by the users.

Figure 5: Technology acceptance model 2 (TAM 2)

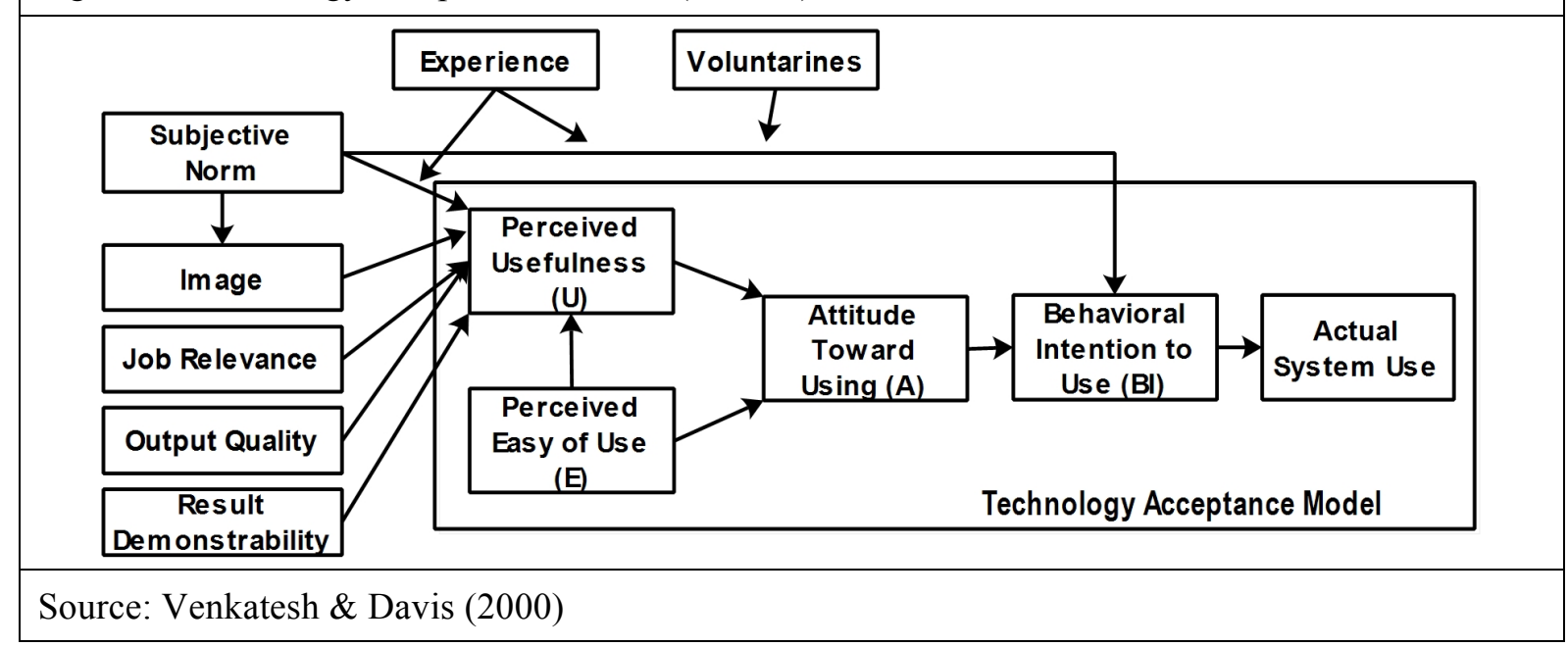

\section{Technology Acceptance 3 (TAM3)}

The TAM3 (Figure 6) presented a complete nomological network of the determinants of IT adoption and use. The strength of TAM3 was its comprehensiveness and potential for actionable guidance. Different from TAM, which presented a parsimonious model, this model aimed to identify general determinants of the two already established core constructs, the perceived usefulness, and perceived ease of use. This model added richness and insight to the understanding of user reactions with new ITs in the workplace. Comprehensiveness and parsimony have their own merits in theory development. While comprehensiveness ensures whether all relevant factors are included in a theory, parsimony dictates whether some factors should be deleted because they add little value to common understanding of a phenomenon (Venkatesh \& Bala, 2008). Four constructs were defined as determinants for the core constructs in terms of perceived ease of use and perceived usefulness: 'individual differences', 'system characteristics', 'social influence', and 'facilitating conditions'. The TAM3 was the first model to introduce individual differences into the field of technology acceptance.

\section{Unified Theory of Acceptance and Use of Technology (UTAUT)}

Venkatesh et al. (2003) attempted to review and compare the existing user-acceptance models with an ultimate goal to develop a unified theory of technology acceptance, by integrating every determinant of user acceptance that was evaluated as important by their longitudinal study. This new model, which was conceptualized and tested. was named unified theory of acceptance and use of technology (UTAUT; Figure 7).

The eight original models and theories of individual acceptance that were integrated by Venkatesh et al. (2003) included the TRA, TAM, MM, TPB, model combining the technology acceptance model and theory of planned behavior (C-TAM-TPB), model of personal computer utilization (MPCU), 
innovation diffusion theory (IDT), and social cognitive theory (SCT). A summary of these models and their constructs are listed in Table 1.

Figure 6: Technology Acceptance 3 (TAM3)

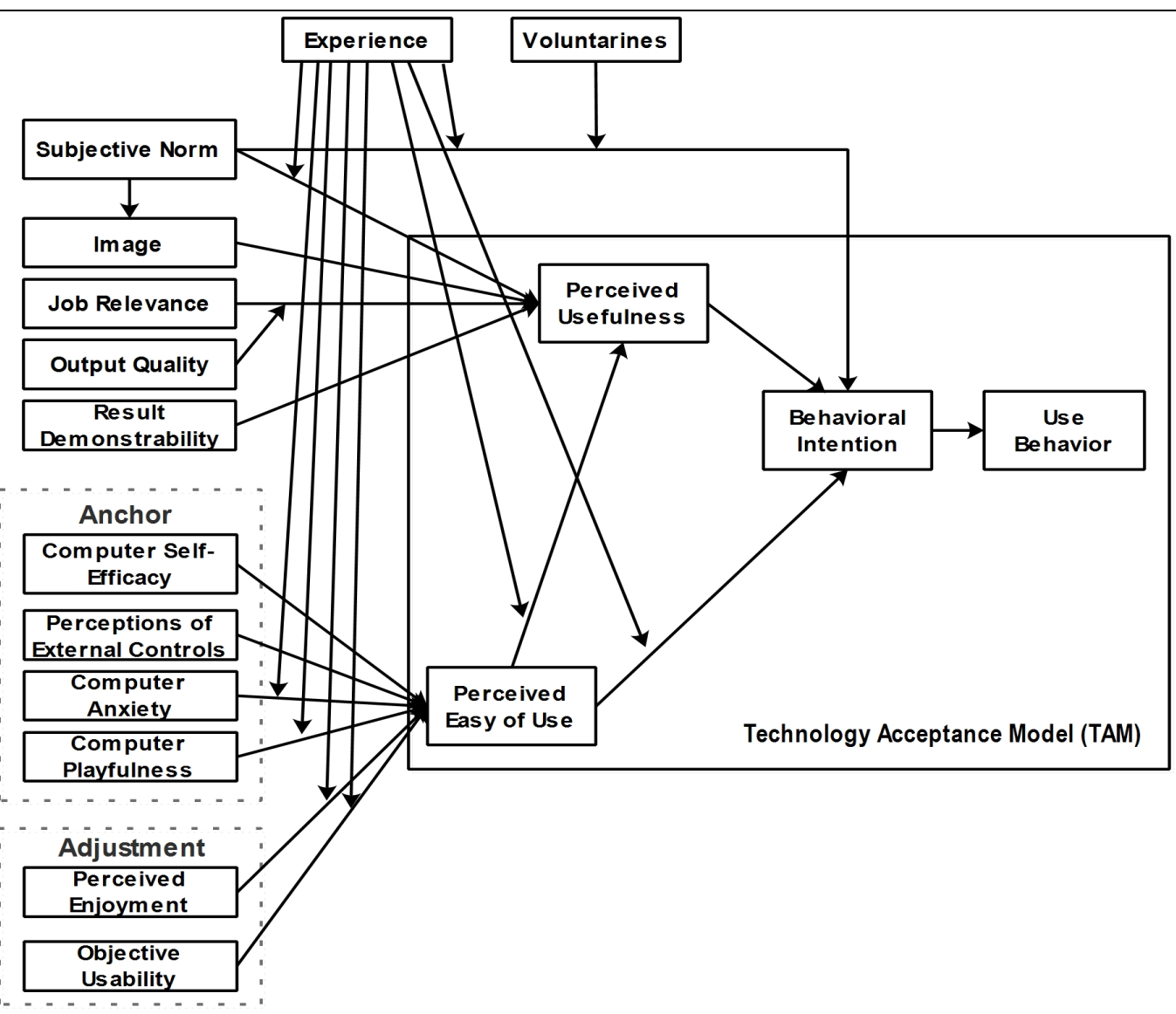

Source: Venkatesh and Bala (2008)

Figure 7: Unified theory of acceptance and use of technology (UTAUT)

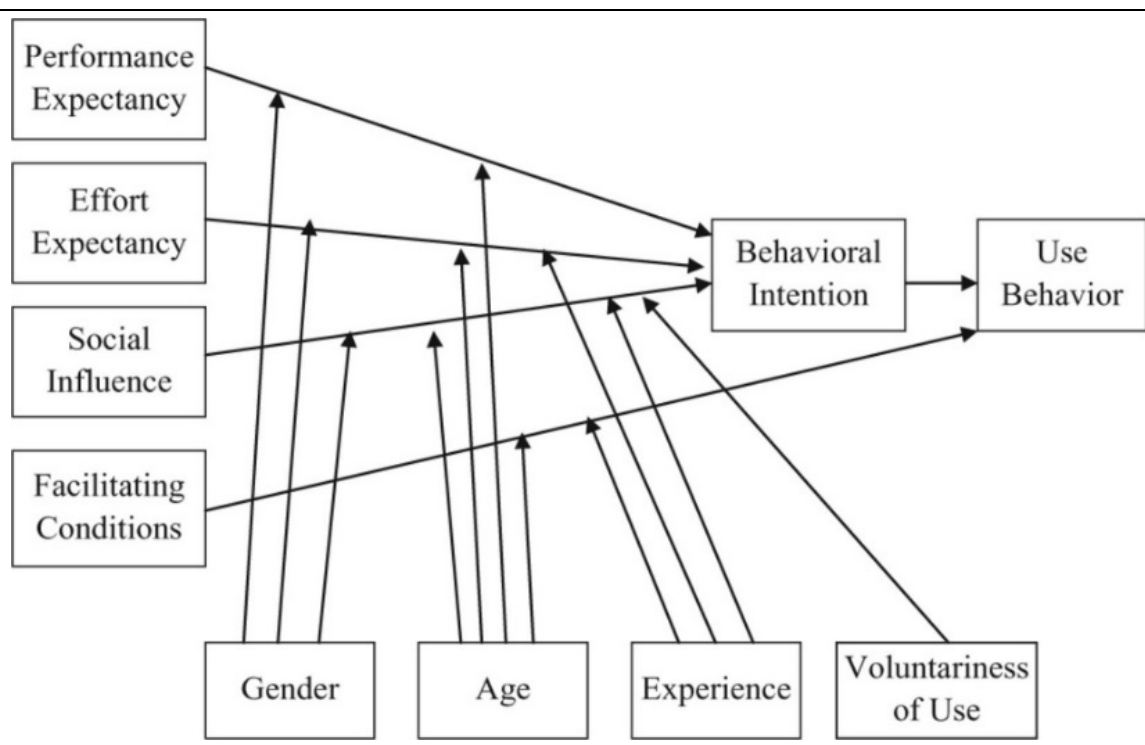

Source: Venkatesh et al. (2003) 
Table 1: Information technology acceptance model used by unified theory of acceptance and use of technology

\begin{tabular}{|c|c|}
\hline Models and Theories & Constructs Used \\
\hline $\begin{array}{l}\text { Theory of Reasoned Action (TRA) by (Fishbein \& } \\
\text { Ajzen, 1975) derives from psychology to measure } \\
\text { behavioral intention and performance. }\end{array}$ & $\begin{array}{l}\text { Attitude } \\
\text { Subjective norm }\end{array}$ \\
\hline $\begin{array}{l}\text { Technology Acceptance Model (TAM) by (F. } \\
\text { Davis, Bagozzi, \& Warshaw, 1989; F. D. Davis, } \\
\text { 1989) develops new scale with two specific } \\
\text { variables to determine user acceptance of } \\
\text { technology. }\end{array}$ & $\begin{array}{l}\text { Perceived Usefulness } \\
\text { Perceived Ease of Use }\end{array}$ \\
\hline $\begin{array}{l}\text { Technology Acceptance Model } 2 \text { (TAM2) by } \\
\text { (Venkatesh \& Davis, 2000) is adapted from TAM } \\
\text { and includes more variables. }\end{array}$ & $\begin{array}{l}\text { Subjective Norm } \\
\text { Experience } \\
\text { Voluntariness*Image } \\
\text { Job Relevance } \\
\text { Output Quality } \\
\text { Result Demonstrability }\end{array}$ \\
\hline $\begin{array}{l}\text { Motivational Model (MM) also stems from } \\
\text { psychology to explain behavior. (F. D. Davis, } \\
\text { Bagozzi, \& Warshaw, 1992) applies this model to } \\
\text { the technology adoption and use. }\end{array}$ & $\begin{array}{l}\text { Extrinsic Motivation } \\
\text { Intrinsic Motivation }\end{array}$ \\
\hline $\begin{array}{l}\text { Theory of Planned Behavior (TPB) by (Ajzen, } \\
\text { 1985, 1991) extends TRA by including one more } \\
\text { variable to determine intention and behavior. }\end{array}$ & $\begin{array}{l}\text { Attitude } \\
\text { Subjective norm } \\
\text { Perceived Behavioral Control }\end{array}$ \\
\hline $\begin{array}{l}\text { Combined TAM and TPB (C-TAM-TPB) by } \\
\text { (Taylor \& Todd, 1995) }\end{array}$ & $\begin{array}{l}\text { Perceived Usefulness } \\
\text { Perceived Ease of Use } \\
\text { Attitude } \\
\text { Subjective norm } \\
\text { Perceived Behavioral Control }\end{array}$ \\
\hline $\begin{array}{l}\text { Model of PC Utilization (MPCU) by (Thompson, } \\
\text { Higgins, \& Howell, 1991) is adjusted from the } \\
\text { theory of attitudes and behavior by Triandis (1980) } \\
\text { to predict PC usage behavior. }\end{array}$ & $\begin{array}{l}\text { Social Factors } \\
\text { Affect } \\
\text { Perceived Consequences (Complexity, Job-Fit, } \\
\text { Long-Term Consequences of Use) } \\
\text { Facilitating Conditions } \\
\text { Habits }\end{array}$ \\
\hline $\begin{array}{l}\text { Innovation Diffusion Theory (IDT) by Rogers } \\
\text { (1962) is adapted to information systems } \\
\text { innovations by (Moore \& Benbasat, 1991). Five } \\
\text { attributes from Rogers' model and two additional } \\
\text { constructs are identified. }\end{array}$ & $\begin{array}{l}\text { Relative Advantage } \\
\text { Compatibility } \\
\text { Complexity } \\
\text { Observability } \\
\text { Trials } \\
\text { Image } \\
\text { Voluntariness of Use } \\
\end{array}$ \\
\hline $\begin{array}{l}\text { Social Cognitive Theory (SCT) by Bandura (1986) } \\
\text { is applied to information systems by (Compeau \& } \\
\text { Higgins, 1995a, 1995b) to determine the usage. }\end{array}$ & $\begin{array}{l}\text { Encouragement by Others } \\
\text { Others' Use } \\
\text { Support } \\
\text { Self-Efficacy } \\
\text { Performance Outcome Expectations } \\
\text { Personal Outcome Expectations } \\
\text { Affect } \\
\text { Anxiety }\end{array}$ \\
\hline $\begin{array}{l}\text { Unified Theory of Acceptance and Use of } \\
\text { Technology Model (UTAUT) by (Venkatesh et al., } \\
\text { 2003)integrates above theories and models to } \\
\text { measure user intention and usage on technology }\end{array}$ & $\begin{array}{l}\text { Performance Expectancy } \\
\text { Effort Expectancy } \\
\text { Attitude toward Using Technology } \\
\text { Social Influence } \\
\text { Facilitating Conditions } \\
\text { Self-Efficacy } \\
\text { Anxiety }\end{array}$ \\
\hline
\end{tabular}

Source: Venkatesh et al. (2003) 
Longitudinal field studies were conducted across heterogeneous contexts. The reliability and validity of each construct from every model were measured. For the new research model, seven constructs appeared to be significant and directly determined the intention of information technology usage. These seven constructs are:

1. Performance expectancy: the degree to which an individual believes that using a particular system would improve his or her job performance;

2. Effort expectancy: the degree of simplicity associated with the use of a particular system;

3. Attitude toward using technology: the degree to which an individual believes he or she should use a particular system;

4. Social influence: the degree to which an individual perceives that others believe he or she should use a particular system;

5. Facilitating conditions: the degree to which an individual believes that an organizational and technical infrastructure exists to support the use of a particular system;

6. Self-efficacy: the degree to which an individual will judge his or her ability to use a particular system to accomplish a particular job or task; and

7. Anxiety: the degree of anxious or emotional reactions associated with the use of a particular system.

\section{Unified Theory of Acceptance and Use of Technology II (UTAUT2)}

The UTAUT2 (Figure 8) is an adapted model of UTAUT from the consumer context. The UTAUT2 incorporates three constructs, identified from previous research in the consumer area into UTAUT: hedonic motivation, price value, and habit. Individual differences in age, gender, and experience, moderate the effects of these constructs on behavioral intention and technology use. Supporting this model were the results from a two-stage online survey over four months that collected technologicaluse data from 1,512 mobile Internet consumers. Compared to UTAUT, the extensions proposed in UTAUT2 produced a substantial improvement in the variance explained in behavioral intention (56 percent to 74 percent) and technological use ( 40 percent to 52 percent; Venkatesh, Thong, \& Xu, 2012)

Figure 8: Unified theory of acceptance and use of technology II (UTAUT2)

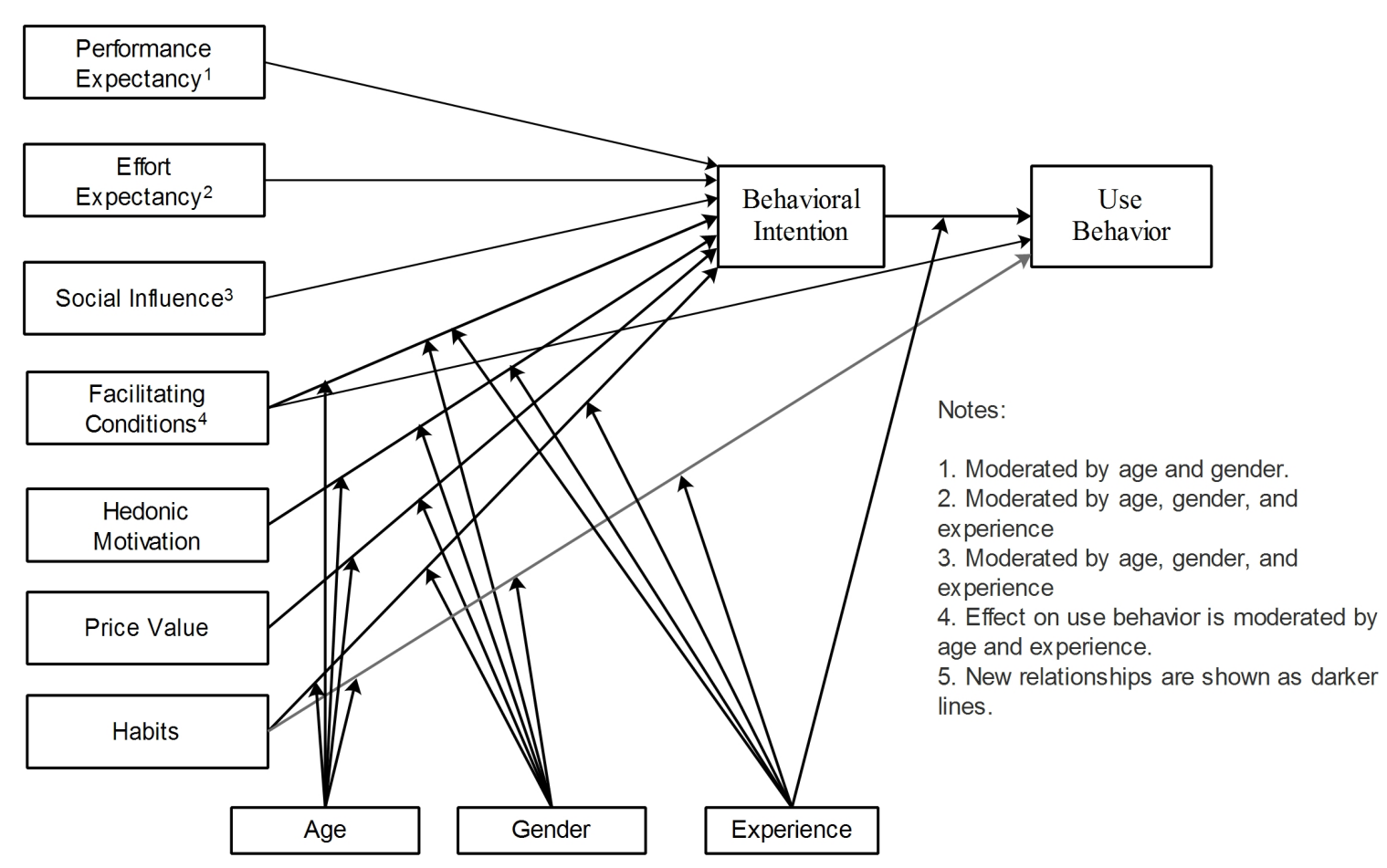

Source: Venkatesh, Chan, \& Thong (2012) 


\section{Mandatory Versus Voluntary environment}

A voluntary-use environment is one in which users perceive the technological adoption or use of as a willful choice; a mandated environment is where users perceive the use to be organizationally compulsory (Hartwick \& Barki, 1994; Venkatesh \& Davis, 2000). Though these appear distinct, a number of issues surround the notion of mandatory compared with volitional usage and these have been raised in the literature. Some research suggests that there is a continuum of voluntariness (e.g., compulsory; Hartwick \& Barki, 1994; Moore \& Benbasat, 1991), such that a given adoption decision may seem more or less voluntary to the users. Even on the same system settings, users can have variable perception of voluntariness. According to Hartwick \& Barki (1994), even in mandatory use, behavior is variable because employees can vary their extent of use. In a mandatory environment, the system use is highly integrated across job functions, more than in the behavior intentions.

The successful adoption of technology, in mandatory environments, relates to user satisfaction, rather than behavioral intention. DeLone and McLean (1992) suggested that user satisfaction is probably the most widely used single measure of IT success. In this study, we will measure the user satisfaction as a surrogate for the success of technology adoption.

\section{Development of Conceptual Model and Methodology}

To develop our model, we reviewed the models mentioned above using the list of their constructs and their theorized relationships. Additional constructs from previous IT research in e-government were also identified to improve predictability. Most models assumed the voluntary use of the technology. Even models that included the possibility of mandatory use through the construct of 'perceived behavioral control', did not apply full mandatory use of the technology. The 'perceived behavioral control' or theory of planned behavior is described as "an individual's perceived ease or difficulty of performing the particular behaviour" (Ajzek, 1991). It is assumed that perceived behavioral control is determined by the total set of accessible control beliefs.

By carefully reviewing the above mentioned models, the relevant constructs were identified (Figure 9), by adapting the UTAUT with 'hedonic motivation' from the UTAUT2, with 'perceived risk' from the work of Susanto and Goodwin (2013), with 'attitude toward behavior' from the TPB, and with 'use satisfaction' from the work of Delone and McLean (2003). All constructs were from previously wellestablished research.

Figure 9: Research model of mandatory e-government

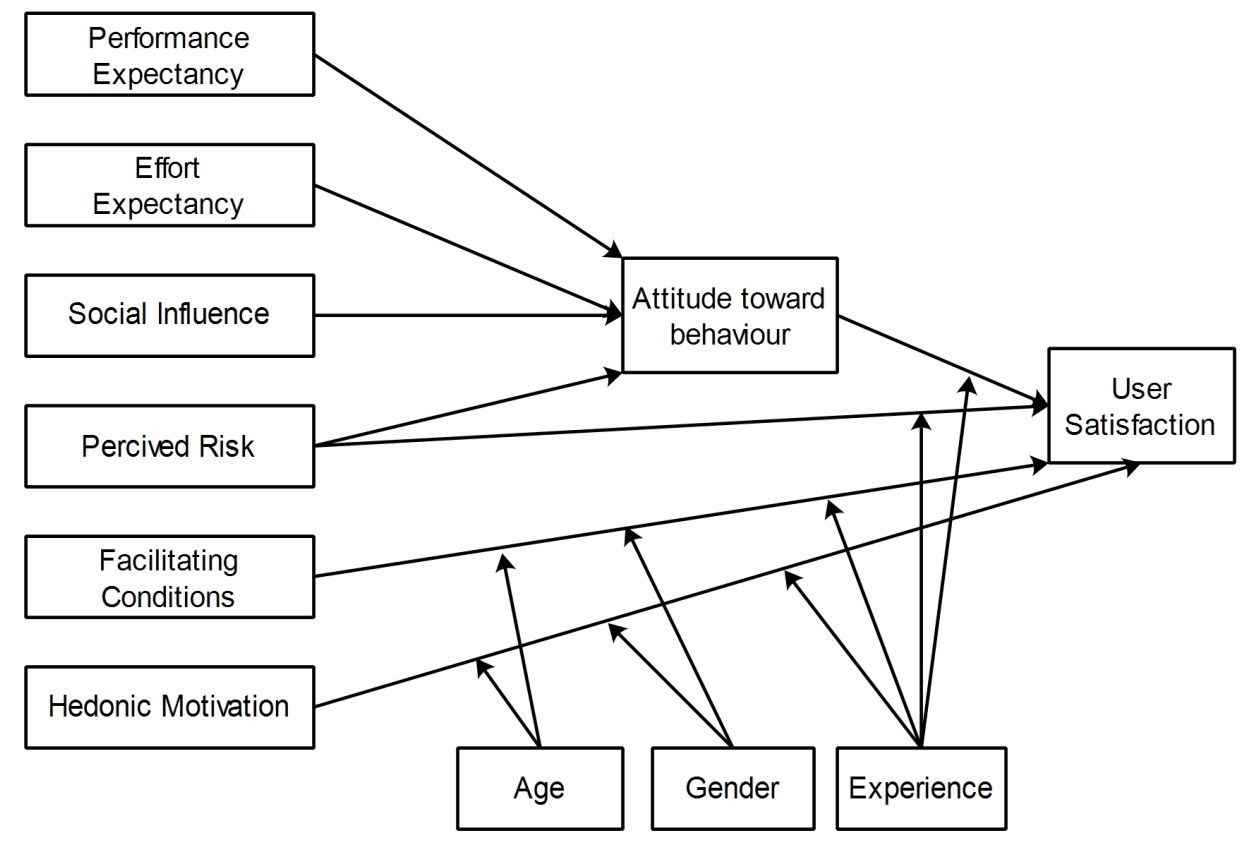

Source: Author 
Attitude is an important determinant in the TRA and the original TAM. Attitude toward behavior refers to "the degree to which a person has a favourable or unfavourable evaluation or appraisal of the behavior in question" (Ajzen, 1991, p. 188). The concept is the degree in which performance of the behavior is positively or negatively valued. Later studies have shown that the TAM had a similar explanatory power with 'attitude' removed. This was a conclusion of studies undertaken mostly in volitional use of systems. In mandatory use of systems, the result of TAM versions (TAM, TAM2, TAM3, and UTAUT) had contradictory results. There have been arguments that the removal of 'attitude' might be the reason for this result (Brown, Massey, Montoya-Weiss, \& Burkman, 2002). Hence, attitude was included in this study's model.

The four core technology adoption beliefs, identified by Venkatesh et al. (2003), and the hedonic motivation in UTAUT2, remain the core construct in this study's model. Performance expectancy, effort expectancy, and social influence are expected to positively and directly influence attitudes toward mandatory use of the system. Attitude toward behavior is expected to fully mediate the model effect positively for user satisfaction.

Hedonic motivation is defined as "the fun or pleasure derived from using a technology, and it has been shown to play an important role in determining technology acceptance and use" (Venkatesh, Thong, \& $\mathrm{Xu}, 2012$, p. 161). It is expected to influence 'technology adoption' and 'user satisfaction'.

Perceived risk is defined as the degree to which a person believes that using the e-government service may cause problems for him or her. Perceived risk has long been confirmed as a determinant of attitude in the context of consumer behavior and diffusion of innovations (Susanto \& Goodwin, 2013). The more users perceive using the e-government service as risky, the more negative will be their attitude toward using it. It is expected that the perceived risk will negatively affect the 'attitude toward the behavior' and negatively affect the 'user satisfaction'.

From this reasoning, the list of hypothesis is defined as:

- H1: Performance expectancy will positively influence attitude toward use of the system;

- H2. Effort expectancy will positively influence attitude toward use of the system;

- H3. Social influence will positively influence attitude toward use of the system;

- H4. Perceived risk will negatively influence attitude toward use of the system;

- H5. Perceived risk will negatively influence user satisfaction;

- H6. Facilitating conditions will positively influence user satisfaction;

- H7. Hedonic motivation will positively influence user satisfaction; and

- H8. Attitude toward use of the system will positively influence user satisfaction

The research model conceptualized in Figure 9 will be tested through a questionnaire. For distributing the questionnaire to the notaries of Albania, an agreement has been formed with the Albanian National Chamber of Notaries. The questionnaire is under development and after a pre-test with a small group of notaries, will be available online with the link sent by email to all notaries.

\section{Conclusions}

Adoption of the digital notarial system in Albania needs to be critically discussed, systematically measured, and monitored using unbiased methodology. Because an understanding of the factors that affect users in adopting technology is highly important for business and the government, several technology adoption models have been developed and tested in the IT research field. However, the focus of these models has been on a voluntary system of use and mainly from a business context, with little emphasis from the context of e-government.

A major distinction between e-government and other online business technologies, is that the use of certain e-government technologies is mandatory, rather than voluntary. Digital notarial is an egovernment system that is mandatory for the notaries to use. The existing models of adoption do not fully apply in this situation and hence, a new model needs to be developed and tested.

The conceptual model developed in this study defines the factors that especially affect the adoption of notaries to the digital notarial system under a mandatory environment. It better explains the mandatory e-government system, by taking into consideration previous research on use of volitional and mandatory systems. An improved model of user adoption and satisfaction for mandatory system will 
allow governments to better understand their system user's motivations. With a better understating of user satisfaction with the system, the government can plan and implement effective interventions. By focusing on the most important user-satisfaction determinants, the government could increase the general acceptance of the system, with less resources.

\section{References}

Ajzen, I. (1985). From Intentions to Actions: A Theory of Planned Behavior. In J. Kuhl \& J. Beckmann (Eds.), Action Control (pp. 11-39). Berlin, Heidelberg: Springer Berlin Heidelberg. http://doi.org/10.1007/978-3-642-69746-3 2

Ajzen, I. (1991). The theory of planned behavior. Organizational Behavior and Human Decision Processes, 50, 179-211. http://doi.org/10.1016/0749-5978(91)90020-T

Ajzen, I., \& Fishbein, M. (1977). Attitude-behavior relations: A theoretical analysis and review of empirical research. Psychological Bulletin, 84(5), 888-918. http://doi.org/10.1037/0033-2909.84.5.888

Brown, S. A., Massey, A. P., Montoya-Weiss, M. M., \& Burkman, J. R. (2002). Do I really have to? User acceptance of mandated technology. European Journal of Information Systems, 11(4).

Brown, S. A., Venkatesh, V., \& Goyal, S. (2012). Expectation Confirmation in Technology Use. Information Systems Research, 23(2), 474-487. http://doi.org/10.1287/isre.1110.0357

Compeau, D. R., \& Higgins, C. A. (1995a). Application of Social Cognitive Theory to Training for Computer Skills. Information Systems Research, 6(2), 118-143. http://doi.org/Article

Compeau, D. R., \& Higgins, C. A. (1995b). Computer self-efficacy: development of a measure and initial test. MIS Quarterly, 19(2), 189-211. http://doi.org/10.2307/249688

Davis, F., Bagozzi, R., \& Warshaw, P. (1989). User acceptance of computer technology: a comparison of two theoretical models. Management Science. http://doi.org/10.1287/mnsc.35.8.982

Davis, F. D. (1989). Perceived Usefulness, Perceived Ease of Use, and User Acceptance of Information Technology, 13(3), 319-340.

Davis, F. D., Bagozzi, R. P., \& Warshaw, P. R. (1992). Extrinsic and Intrinsic Motivation to Use Computers in the Workplace1. Journal of Applied Social Psychology, 22(14), 1111-1132. http://doi.org/10.1111/j.1559-1816.1992.tb00945.x

DeLone, W. H., \& McLean, E. R. (1992). Information systems success: The quest for the dependent variable. Information Systems Research, 3(1), 60-95. http://doi.org/10.1287/isre.3.1.60

Delone, W. H., \& McLean, E. R. (2003). The DeLone and McLean model of information systems success: a ten-year update. Journal of Management Information Systems / Spring, 19(4), 9-30. http://doi.org/10.1073/pnas.0914199107

Deloitte Research, Deloitte \& Touche, \& Deloitte Consulting (2000). At the dawn of e-Government: the citizen as customer. Deloitte Consulting, New York.

Fishbein, M., \& Ajzen, I. (1975). Belief, Attitude, Intention, and Behavior, An Introduction to Theory and Research.

Goodhue, D. L., \& Thompson, R. L. (1995). Task-Technology Fit and Individual Performance. MIS Quarterly, 19(2), 213. http://doi.org/10.2307/249689

Gupta, B., Dasgupta, S., \& Gupta, A. (2008). Adoption of ICT in a government organization in a developing country: An empirical study. The Journal of Strategic Information Systems, 17(2), 140-154. http://doi.org/10.1016/j.jsis.2007.12.004

Hartwick, J., \& Barki, H. (1994). Explaining the Role of User Participation in Information System Use. Management Science, 40(4), 440-465. http://doi.org/10.1287/mnsc.40.4.440

Malavet, P. A. (1995). Counsel for the Situation: The Latin Notary, a Historical and Comparative Model. Hastings International and Comparative Law Review, 19(3), 389-490.

Min, T., \& Park, C. (2008). Mobile technology usage and B2B market performance under mandatory adoption. Industrial Marketing Management, 37(7), 833-840. http://doi.org/10.1016/j.indmarman.2008.02.008

Moore, G. C., \& Benbasat, I. (1991). Development of an instrument to measure the perceptions of adopting an information technology innovation. Information Systems Research, 2(3), 192-222. http://doi.org/10.1287/isre.2.3.192

O'Connor, R. C., \& Armitage, C. J. (2003). Theory of planned behaviour and parasuicide: An exploratory study. Current Psychology, 22(3), 196-205. http://doi.org/10.1007/s12144-003-1016-4

Rogers, E. M. (1995). DIFFUSION OF INNOVATIONS. Elements of Diffusion (4th ed.). THE FREE PRESS. http://doi.org/citeulike-article-id:126680

Sheppard, B. H., Hartwick, J., \& Warshaw, P. R. (1988). The Theory of Reasoned Action: A Meta-Analysis of Past Research with Recommendations for Modifications and Future Research. Journal of Consumer Research, 15(3), 325-343. http://doi.org/http://dx.doi.org/10.1086/209170

Susanto, T. D., \& Goodwin, R. (2013). User acceptance of SMS-based e-government services: Differences between adopters and non-adopters. Government Information Quarterly, 30(4), 486-497. http://doi.org/10.1016/j.giq.2013.05.010

Taylor, S., \& Todd, P. A. (1995). Understanding information technology usage: A test of competing models. Information Systems Research. http://doi.org/10.1287/isre.6.2.144

Thompson, R. L., Higgins, C. A., \& Howell, J. M. (1991). Personal Computing: Toward a Conceptual Model of Utilization. MIS Quarterly, 15(1), 125-143. http://doi.org/10.2307/249443 
Tornatzky, L. G., \& Fleischer, M. (1990). The processes of technological innovation. The Journal of Technology Transfer, 16(1), 45-46. http://doi.org/10.1007/BF02371446

United Nations Department of Economic and Social Affair. (2014). United Nations E-Government Survey 2014: EGovernment for the Future We Want.

Venkatesh, V., \& Bala, H. (2008). Technology acceptance model 3 and a research agenda on interventions. Decision Sciences, 39(2), 273-315. http://doi.org/10.1111/j.1540-5915.2008.00192.x

Venkatesh, V., Chan, F. K. Y., \& Thong, J. Y. L. (2012). Designing e-government services: Key service attributes and citizens' preference structures. Journal of Operations Management, 30(1-2), 116-133. http://doi.org/10.1016/j.jom.2011.10.001

Venkatesh, V., \& Davis, F. D. (2000). A Theoretical Extension of the Technology Acceptance Model: Four Longitudinal Field Studies. Management Science, 46(2), 186-204. http://doi.org/10.1287/mnsc.46.2.186.11926

Venkatesh, V., Morris, M. G., Hall, M., Davis, G. B., Davis, F. D., \& Walton, S. M. (2003). User acceptance of information technology: Toward a unified view. MIS Quarterly, 27(3), 425-478. http://doi.org/10.2307/30036540

Venkatesh, V., Thong, J., \& Xu, X. (2012). Consumer acceptance and user of information technology: Extending the unified theory of acceptance and use of technology. MIS Quarterly, 36(1), 157-178.

Warkentin, M., Gefen, D., Pavlou, P. a., \& Rose, G. M. (2002). Encouraging Citizen Adoption of e-Government by Building Trust. Electronic Markets, 12(3), 157-162. http://doi.org/10.1080/101967802320245929 